\title{
Penguatan Industri Rumah Tangga Dodol Buah Naga Sebagai Bentuk Pemenuhan Hak Ekonomi Masyarakat Di Desa Temurejo Kecamatan Bangorejo Kabupaten Banyuwangi
}

\author{
Al Khanif, Dina Tsalist Wildana, Dyah Ochtorina S \\ Fakultas Hukum Universitas Jember \\ al_khanif@unej.ac.id
}

\begin{abstract}
Abstrak
Persoalan mendasar terkait produksi pertanian dan perkebunan di Indonesia adalah ketidak mampuan petani untuk mengolah produk-produk yang mereka hasilkan menjadi produk olahan. Persoalan ini juga dihadapi oleh para petani buah naga di Desa Temurejo Kecamatan Bangorejo Kabupaten Banyuwangi Jawa Timur yang selama ini selalu menjual buah naga dalam kondisi segar. Model penjualan produk pertanian seperti ini mengancam ketahanan ekonomi para petani karena harga jual buah naga menjadi tidak menentu dan cenderung murah ketika panen raya. Berdasarkan persoalan tersebut, perlu kiranya ada solusi untuk membantu petani buah naga agar mereka mendapatkan keuntungan yang sepadan. Salah satunya adalah pengenalan tentang pengolahan buah naga menjadi dodol buah naga. Salah satu hasil dari program ini adalah kemampuan petani untuk mengolah produk buah naga menjadi dodol buah naga. Program pengabdian ini juga berhasil mengembangkan koordinasi yang lebih intensif antara perajin dodol dengan pihak desa. Namun demikian, penelitian ini juga menemukan kendala pemasaran dari produk dodol tersebut sehingga merekomendasikan perlunya kajian lebih lanjut melalui program pengabdian lain di tahun mendatang.
\end{abstract}

Kata Kunci: Dodol, Buah Naga, UMKM

\section{PENDAHULUAN}

Kabupaten Banyuwangi sudah lama terkenal sebagai kabupaten penghasil jeruk, terutama di bagian Selatan Banyuwangi. Namun dalam lima tahun terakhir kabupaten di ujung timur Jawa Timur itu juga terkenal sebagai penghasil buah naga yang juga banyak tumbuh di daerah yang sama. Ada dua varian buah naga yang dikembangkan di Banyuwangi yaitu buah naga yang berwarna merah atau dikenal dengan sebutan hylocereus costaricensis dan yang berwarna putih atau juga dikenal dengan sebutan hylocereus undatus. Masyarakat tidak hanya menanam buah naga di lahan-lahan produktif pertanian melainkan juga di pekarangan rumah. Di sentra penghasil buah naga, nyaris tidak ada lagi masyarakat yang menanam padi sebagai tanaman pokok. Buah naga seperti sudah menjadi urat nadi kehidupan masyarakat.

Karena perubahan pola tanam petani dari petani padi dan jeruk menjadi petani buah naga, kini Banyuwangi bersama dengan Kalimatan Timur merupakan daerah penghasil buah naga terbesar di Indonesia. Produksi buah naga Kabupaten Banyuwangi 
secara keseluruhan adalah sekitar 20 ribu ton per tahun dengan panen raya yang terjadi antara bulan Januari sampai Mei setiap tahunnya. Sampai dengan tahun 2015, produksi buah naga menempati posisi ke sembilan komoditas buah-buahan di kabupaten yang terkenal dengan sebutan Sunrise van Java tersebut. Hingga kini buah naga produksi Kabupaten Banyuwangi telah berhasil merambah kota-kota besar di Indonesia baik di Jawa maupun luar Jawa.

Kemampuan Banyuwangi untuk produksi buah naga dalam jumlah besar tersebut harus diapresiasi. Selain memberikan pendapatan tambahan daerah dari pajak, masyarakat juga mendapatkan penghasilan tambahan. Namun sayangnya, jika waktu panen raya tiba, para petani tidak mendapatkan untung besar karena pasokan buah naga yang melimpah. Jika rata-rata harga jual buah naga dari petani sekitar 8000 rupiah atau lebih, panen raya bisa menjatuhkan harga buah naga sampai $50 \%$ atau hanya tinggal 4000 rupiah atau bahkan lebih rendah lagi. Tentu harga yang sangat murah ini tidak menguntungkan petani.

Ketidakpastian harga jual buah naga tersebut disebabkan karena petani buah naga tidak mempunyai kemampuan untuk mengolah buah naga menjadi produk olahan sehingga mereka harus menjual buah naga mereka dalam kondisi segar. Sehingga kondisi ini dimanfaatkan oleh pelaku pasar untuk memainkan harga buah naga. Padahal prinsip ekonomi akan berlaku jika produksi melimpah sedangkan permintaan tetap maka harga komoditas tersebut akan menjadi murah. Namun petani tidak mengenal rumus ekonomi tersebut. Yang mereka kenal adalah mimpi untuk mendapatkan keuntungan yang melimpah yang tentu saja tidak mudah terlaksana jika tidak ada manajemen produksi yang memadai. Ketidakmampuan dan kurangnya pengetahuan untuk membuat produk olahan berbasis buah naga ini pada akhirnya justru akan membuat petani buah naga terjebak dalam kemiskinan.

Untuk mengatasi persoalan tersebut, pemerintah Desa Temurejo Kecamatan Bangorejo Kabupaten Banyuwangi yang menjadi objek dari program pengabdian ini sebenarnya sudah mengadakan pelatihan pembuatan produk olahan buah naga berupa dodol buah naga. Menurut Fuad Musyadad, Kepala Desa Temurejo, sudah ada dua kali pelatihan pembuatan dodol yang melibatkan beberapa petani buah naga selama dua tahun terakhir. Namun sayangnya pelatihan tersebut tidak berjalan baik karena produknya tidak jadi dan petani tidak mampu meneruskan pembuatan dodol buah naga secara mandiri. Pemerintah Desa juga tidak mempunyai program lanjutan untuk mendukung pengembangan produk olahan tersebut sehingga inisiatif yang baik dari desa tersebut harus didukung oleh berbagai pihak agar usaha untuk mengembangkan produk olahan berbahan buah naga dapat berjalan.

Salah satu perkumpulan petani yang terus berupaya untuk mengembangkan produk olahan berbahan buah naga adalah Kelompok Tani Puspa Naga yang berada di Dusun Selorejo Desa Temurejo. Kelompok tani yang didirikan pada tahun 2016 tersebut terdiri dari sekitar lima pengrajin dodol buah naga di dusun setempat. Mereka juga mempunyai kebun buah naga yang mereka tanam dan olah sendiri. Namun sayangnya, produksi dodol buah naga yang menjadi satu-satunya produk mereka hanya dibuat 
berdasarkan pesanan. Selain itu, mereka juga membuat dodol buah naga selama musim panen raya (sekitar Januari - Mei) setiap tahunnya ketika harga buah naga jatuh.

Sebenarnya Adanya inovasi dodol buah naga yang dilakukan oleh UMKM Puspa Naga bersama dengan masyarakat/petani buah naga harus diapresiasi oleh pemerintah setempat. Memang produk dodol buah naga di UMKM Puspa Naga bukanlah produksi dodol buah naga yang pertama karena sudah ada beberapa daerah yang telah memproduksi dodol dengan bahan baku buah naga. Namun demikian, sebagai industri rumahan yang dikerjakan oleh pengrajin yang terbatas, baik dari segi jumlah maupun pengetahuan tentang pengolahan dan pemasaran produk, tentu Puspa Naga sangat membutuhkan bantuan dari pemerintah desa setempat. Jika tidak, usaha untuk mengembangkan dodol buah naga yang dilakukan oleh Puspa Naga akan sangat sulit bersaing dengan produk lain.

Saat ini Pemerintah Kabupaten Banyuwangi dapat dimasukkan kedalam kategori daerah yang mampu memaksimalkan perannya di era otonomi daerah. Berbagai inovasi dan kebijakan yang berorientasi kepada pembangunan manusia, industri kreatif dan pemanfaatan sumber daya alam telah membawa dampak positif terhadap perekonomian masyarakat. Kabupaten Banyuwangi juga dikenal ramah terhadap investasi sehingga dalam kurun waktu kurang lebih sepuluh tahun terakhir ada beragam investasi yang mulai menanamkan modalnya di Banyuwangi mulai industri jasa perhotelan dan pertambangan.

Namun sayangnya, model kebijakan Pemerintah Banyuwangi masih terfokus pada pariwisata seperti industri batik yang dilibatkan dalam even tahunan Banyuwangi Batik Festival. Padahal keterlibatan Pemerintah Kabupaten Banyuwangi dalam memajukan industri kecil dan menengah tergolong bagus dan sudah dijadikan standar pembelajaran dari pemerintah daerah lain. Tentu modal ini harus didukung oleh segenap elemen pemerintah daerah agar ada sinergitas antara pengrajin dan pemerintah daerah. Selain itu, Pemerintah Kabupaten Banyuwangi juga harus menyadari bahwa pengembangan industri rumah tangga yang dijalankan oleh Puspa Naga merupakan tanggungjawab pemerintah karena menyediakan lapangan pekerjaan dan berpotensi untuk menyumbang bagi perikehidupan yang lebih bermartabat bagi para pengrajin buah naga.

Selama ini, intervensi pemerintah Kabupaten Banyuwangi terkait pengembangan buah naga adalah pengenalan pupuk organik. Hal ini dikarenakan hampir semua tananam buah naga yang ada di Banyuwangi masih menggunakan pupuk kimiawi untuk memaksimalkan produksi buah naga. Bahkan ketika program pengabdian ini dilaksanakan, mayoritas petani buah naga masih menggunakan pupuk kimia. Masih adanya petani dengan pupuk kimiawi mengindikasikan bahwa sosialisasi yang dilakukan oleh Pemda belum maksimal apalagi dibidang hilir dari budidaya buah naga tersebut. Sampai saat ini, Pemda Banyuwangi belum melakukan kebijakan untuk mengintegrasikan inovasi masyarakat dengan kegiatan ekonomi di skala lokal maupun regional. Seharusnya, pemerintah berkewajiban untuk merumuskan strategi pembangunan ekonomi daerah dengan menciptakan langkah-langkah yang terintegrasi 
untuk mempromosikan inovasi dodol buah naga sebagai bagian dari penghargaan pemda terhadap inovasi masyarakatnya dan untuk menumbuhkembangkan kreatifitas di masyarakat.

Intervensi positif dari Pemda Banyuwangi sangat dibutuhkan untuk tidak hanya memenuhi hak-hak ekonomi dan pekerjaan masyarakat melainkan juga untuk menjadikan program kebijakan pemda yang berdimensi kemanusiaan. Pendekatan tersebut, yang seringkali dinyatakan sebagai promosi "pembangunan berdimensi kemanusiaan" mengharuskan bahwa tujuan dari perlindungan hak masyarakat miskin dan rentan harus menjadi tujuan utama dari penyesuaian ekonomi. Hal ini disebabkan para petani dan pengrajin buah naga merupakan kalangan masyarakat yang masih tergolong miskin sehingga hak-hak dasar mereka lainnya sangat rentan untuk termarjinalkan. Beberapa diantaranya adalah hak anak-anak mereka terhadap pendidikan dan kesehatan. Jika mereka bisa mengatasi persoalan ekonomi mereka dengan mengembangkan bisnis dodol buah naga, akan sangat mungkin hak-hak dasar mereka juga bisa lebih mudah terpenuhi.

Berangkat dari persoalan diatas, persoalan pengembangan UMKM Puspa Naga dibidang dodol buah naga tidak bisa hanya dimaknai sebagai sebuah persoalan ekonomi semata melainkan ada dimensi lain yang saling berkaitan seperti hak atas pendidikan, hak untuk mengembangkan diri, hak ekonomi dan hak untuk mendapatkan kehidupan yang layak secara ekonomi.

Pendidikan adalah sebuah hak asasi sekaligus sebuah sarana untuk merealisasikan hak-hak asasi manusia lainnya. Pendidikan adalah sarana utama di mana orang dewasa dan anak-anak yang dimarjinalkan secara ekonomi dan sosial dapat mengangkat diri mereka sendiri keluar dari kemiskinan dan memperoleh cara untuk turut terlibat dalam komunitas mereka. Terkait dengan penguatan industri dodol buah naga, persoalan akses pendidikan menjadi penting mengingat pendidikan di Indonesia masih belum benar-benar terbebas dari semua pungutan. Oleh karena itu pemberdayaan ekonomi di masyarakat menjadi salah satu unsur penting yang harus diperhatikan agar masyarakat bisa berdikari dan berdaya.

Berdasarkan realitas diatas, program pengabdian masyarakat ini menjadi sangat penting untuk memperkuat industri rumah tangga dodol naga yang telah digagas oleh Usaha Mikro Kecil dan Menengah (UMKM) Puspa Naga Desa Temurejo. Selain itu, program pengabdian ini juga dimaksudkan untuk memberikan penyuluhan dan pendampingan tata cara membuat dodol buah naga yang tahan lama dengan menggunakan bahan pengawet yang tidak berbahaya bagi kesehatan. Selain itu, hal penting lain yang akan menjadi target dari program pengabdian ini adalah terciptanya hak atas kekayaan intelektual dari usaha dodol buah naga.

Persoalan HKI menjadi permasalahan laten di masyarakat karena ada banyak ragam produk yang diciptakan oleh masyarakat namun belum mendapatkan pengakuan sebagai sebuah hak atas kekayaan intelektual. Padahal Indonesia sebagai salah satu anggota World Trade Organisation (WTO) harus menegakan HKI untuk melindungi produk-produk Indonesia. Padahal di negara-negara maju, HKI sudah 
menjadi bagian yang tak terpisahkan dari bisnis negara dan pelaku swasta karena mereka sudah memahami bahwa setiap penemuan yang mereka hasilkan harus dilindungi oleh hak cipta. Hal ini dikarenakan tidak setiap orang mampu menemukan sebuah inovasi dibidang sains dan sosial.

Oleh karena itu, program pengabdian ini mempunyai tiga permasalahan yang ingin diselesaikan. Pertama, persoalan pendataan masyarakat khususnya masyarakat miskin terkait program pemerintah dibidang pendidikan dan kesehatan. Kedua, persoalan mengenai kemampuan masyarakat untuk menggali dan menerima informasi dari pemerintah terkait program-program yang ditujukan bagi mereka. Ketiga, persoalan mengenai pengawasan program pemerintah bagi masyarakat khususnya keluarga buruh migran dan miskin di Desa Temurejo Kabupaten Banyuwangi.

\section{PERMASALAHAN MITRA}

Desa Temurejo merupakan sebuah desa yang secara administratif masuk kecamatan Bangorejo kabupaten Banyuwangi Propinsi Jawa Timur. Seperti desa-desa yang berada di kabupaten Banyuwangi, Disamping memiliki angka perkawinan dini sudah berhasil di tekan dari tahun ketahun. Tahun 2014 terdapat 9 pasangan 20156 pasangan, 2016 tidak ada perkawinan dini dan 2017 terdengar kabar akan terdapat 1 orang. Itupun masih ada kemungkinan untuk di tunda. Artinya, persoalan utama dari pengrajin buah naga yang ada di Puspa Naga lebih pada penguatan ekonomi masyarakat agar mereka dapat mandiri secara ekonomi.

Di dusun ini terdapat hukum adat yang sangsinya adalah di nggrasak. Semua jenis tindakan pidana yang dilakukan oleh anggota masyarakat di dusun tersebut tidak pernah diserahkan ke polisi atau diajukan ke pengadilan melainkan diselesaikan dalam forum musyawarah adat. Nggrasak tidak dilaksanakan jika pelaku pidana adalah orang luar. Masih kuatnya tradisi nggasak ini juga menyebabkan tingkat kejahatan di Desa Temurejo cenderung rendah.

Persoalan yang selama ini masih ada di Desa Temurejo adalah masih tingginya angka perceraian yang salah satu faktor penyebabnya adalah faktor ekonomi. Umumnya masyarakat bekerja di bidang pertukangan yang pendapatan perharinya mencapai 90.000, sedangkan kuli dibidang pemetikan buah jeruk atau buah naga dilakukan secara borongan yaitu per rit 500.000. Biasanya pemetikan buah baik buah naga atau buah jeruk dilakukan secara kelompok sekitar 4-5 orang yang tiap hari mampu mengerjakan 2 rit. Artinya bekerja disektor ini akan mendapatkan pendapatan paling tidak 200.000-250.000 per hari. Karena pekerjaan ini tergolong berat hanya kaum laki-laki saja yang bekerja di sektor ini.

Meskipun tingkat perekonomian cukup berkembang namun tidak berarti Desa Temurejo khususnya Dusun Selorejo zero TKI. Sampai di tahun 2017, total TKI dari desa ini berjumlah lebih dari 300 orang dengan jenis pekerjaan sebagai PRT yang mayoritas bekerja di Hongkong, Taiwan dan Malaysia. Umumnya hal ini terjadi karena di desa suami tidak kuat bekerja, pendapatan minim sehingga berdasarkan kesepakatan bersama sang istri bekerja di luar negeri untuk membangun rumah tangga. Namun 
tidak sedikit setelah mendapatkan masukan yang cukup dari bekerja sebagai TKI namun malah terjadi perceraian (nyusuki) karena merasa istri lebih mapan dari pada suami.

Persoalan sosial tersebut tentu belum mencerminkan realitas persoalan yang sebenarnya di masyarakat karena masih banyak persoalan lain yang belum terungkap. Disinilah peran dan tanggungjawab pemerintah diperlukan untuk menekan meningkatnya persoalan-persoalan sosial tersebut. Salah satunya dengan cara memaksimalkan potensi desa seperti penguatan industri rumah tangga. Dengan potensi sumber daya alam yang melimpah seperti jeruk dan buah naga, bukan hal sulit tentunya bagi desa untuk membuat kebijakan untuk meningkatkan pendapatan ekonomi masyarakat. Menurut pengakuan Kepala Desa Muhammad Fuad Musyadad, upaya yang telah dilakukan oleh Pemerintah Desa untuk memaksimalkan potensi ekonomi desa adalah mengadakan pelatihan pengolahan jeruk menjadi sirup dan membuat olahan dari buah naga. Namun bisnis ini terkendala dalam hal pemasaran. Permodalan dianggap bukan kendala karena sebagaimana dijelaskan diatas hampir tiap rumah memiliki sumber pemasukan dari buah naga atau jeruk.

Berdasarkan penelitian dan analisis data yang telah dilakukan dapat, diketahui bahwa terdapat perbandingan yang kontras antara biaya produksi terhadap daya jual produk olahan buah naga oleh para petani buah naga di Desa Temurejo Kecamatan Bangorejo Kabupaten Banyuwangi. Yang pertama adalah masih tingginya biaya produksi, khususnya untuk biaya produksi dodol karena proses pembuatannya memerlukan tenaga yang banyak dan waktu yang cukup lama. Padat karya tentu baik untuk membuka lapangan pekerjaan namun juga berkaitan dengan harga produk yang mahal. Ini adalah tantangan yang harus dipecahkan bagi desa, pengrajin dan juga model-model bantuan dari pihak ketiga yang akan datang.

Yang kedua adalah waktu produksi. Dodol buah naga akan mempunyai daya saing produk yang baik jika pembuatannya dilakukan pada saat panen raya ketika harga buah naga sangat murah atau sekitar Rp. 2000 sampai Rp. 3000. Otomatis bahan utama olahan yakni buah naga yang harganya berubah-ubah sesuai musim panennya mempengaruhi harga produksi dari produk tersebut yaitu lebih mahal daripada jika olaha tersebut diproduksi pada saat panen raya. Keterbatasan waktu ini tentu akan berdampak pada keberlangsungan usaha dan juga pemasaran produk mengingat ketersediaan dodol di pasaran akan sangat tergantung pada musim panen buah naga.

Persoalan yang ketiga adalah pemasaran produk. Selayaknya industri kecil lain, Puspa Naga sangat menggantungkan penjualan produknya dari pesanan. Mereka biasanya tidak membuat dodol jika tidak ada pesanan. Namun produksi dodol dalam jumlah besar tentu juga akan berpengaruh terhadap keberhasilan penjualannya. Hingga saat ini dodol yang dibuat oleh Puspa Naga belum mempunyai pengawet atau masih alami sehingga ketahanan produk sangat terbatas.

Yang terakhir adalah jaminan mutu produk yang masih belum seragam. Persoalan ini muncul karena proses pengemasan produk dilakukan secara bersama-sama dan tidak ada yang mengontrol proses akhir sehingga menyebabkan ukuran dodol tidak 
sama. Ketidakseragaman produk akhir tersebut tentu akan mempengaruhi pembeli karena produk akan terlihat seperti produk yang tidak berkualitas.

\section{METODE PELAKSANAAN}

Program pengabdian ini akan menggunakan empat elemen yang saling terintegrasi selama kegiatan. Pertama, Identification Based Program (IBP). IBP ini didesain untuk mengidentifikasi para pengrajin dodol buah naga atau mereka yang berpotensi menjadi pengrajin dodol buah naga. Target/sasaran program dari IBP ini adalah 30 orang pengrajin yang tersebar di seluruh Desa Temurejo. IBP ini dilaksanakan selama dua bulan pertama dari tahun pengabdian.

Kedua, Integrated-Production Based program (IPBP). IPBP merupakan aktifitas yang didesain untuk mengoordinasi para pengrajin untuk secara bersama-sama belajar membuat dodol buah naga yang sesuai dengan standar kesehatan dan higienitas. Beberapa kegiatan yang masuk dalam kategori IPBP adalah menghadirkan konsultan makanan dan gizi, pendampingan pembuatan dodol buah naga, dan pemasaran produk. Program IPBP dilaksanakan mulai bulan ketiga sampai bulan kedelapan dari Program Pengabdian. Program pembuatan dodol buah naga juga disesuaikan dengan masa panen buah naga, yakni mulai Desember sampai Mei setiap tahunnya.

Ketiga, Monitoring and Marketing (M\&M). Program M\&M didesain untuk membuat program capacity building bagi masyarakat dan perwakilan masyarakat setempat yang dianggap mempunyai peluang untuk berperan besar melanjutkan program pasca program pengabdian selesai. Selain itu, program M\&M juga memprioritaskan pada usaha untuk merealisasikan produk luaran berupa jejaring bisnis dan pengetahuan masyarakat tentang manajemen produksi dan pemasaran produk. Semua program M\&M dilaksananakan setelah UMKM Puspa Naga berhasil memproduksi dodol buah naga. Namun target dari program M\&M ini dilaksanakan pada tiga bulan terakhir dari pengabdian. Selain itu, di program terakhir ini juga ada Sharing and Empowering (SE). SE didesain untuk membuat pos layanan berbasis masyarakat yang diharapkan bisa menyediakan berbagai jenis informasi kepada masyarakat sehingga masyarakat menentukan strategi pemasaran produk dodol buah naga. Target luaran dari program SE diharapkan bisa terealisasi pada bulan keempat sampai bulan keenam tahun kedua program pengabdian.

Berangkat dari beberapa persoalan tersebut, kegiatan pengabdian ini merupakan salah satu tahapan penting untuk memetakan persoalan dan kemudian mengajukan model perbaikan yang sesuai dengan kebutuhan Puspa Naga. Selain itu, program ini juga menjadi bagian yang tidak terpisahkan dari kegiatan pengabdian kepada masyarakat sebagai bagian Tridarma Perguruan Tinggi tim selaku pengajar di Universitas Jember. Program pengabdian ini mendesain beberapa kegiatan selama enam bulan.

Dalam pelaksanaannya, kegiatan pengabdian ini terdapat tiga tahapan yakni yang pertama mengenai pelatihan pembuatan dodol buah naga yang dilaksanakan pada tanggal 21-22 Oktober 2017. Pelatihan tersebut selain mendatangkan narasumber di 
bidang pembuatan dodol buah naga untuk menyampaikan bagaimana mengolah buah naga agar menjadi produk olahan yang menarik, juga menghadirkan pihak kesehatan agar dalam produksi olahan tersebut tetap memperhatikan kualitas kesehatan makanan. Pada pelatihan yang pertama ini dihadiri oleh berbagai lapisan masyarakat. Tokoh masyarakat yang hadir antara lain Bapak Kepala Desa Bangorejo beserta istri sebagai Pembina PKK di desa tersebut, beserta seluruh RT dan RW. Masyarakat yang hadir tampak sangat antusias memperhatikan materi pelatihan yang disampaikan, hal ini tampak dari banyaknya masyarakat yang bertanya dan ingin mendapatkan penjelasan lebih mendalam bagaimana ekonomi kreatif bisa mereka kembangkan di wilayah desa mereka melalui pembuatan dodol buah naga tersebut.

Kegiatan pelatihan ini dilakukan dengan metode ceramah, tanya jawab serta praktik pembuatan produk dodol buah naga. Hal tersebut bermaksud untuk memotivasi keinginan masyarakat untuk mengembangkan ide-ide kreatif yang dimiliki untuk memanfaatkan sumberdaya yang tersedia di wilayahnya. Hal ini disebabkan karena potensi sumberdaya Desa Temurejo sangat beragam dan prospek dikembangkan untuk mendukung pembangunan ekonomi kreatif masyarakat. Sumberdaya yang dapat mendukung ekonomi kreatif masyarakat antara lain sumberdaya pertanian (buah naga, jeruk), sumberdaya alam untuk kerajinan (kurungan burung, kerajinan anyaman bambu lain). Sumberdaya yang terpenting yang dimiliki adalah sumberdaya insani yang dimiliki desa untuk pengembangan ekonomi kreatif.

Karena itu, substansi isi materi pelatihan yang disampaikan disesuaikan dengan potensi sumberdaya yang ada di desa. Adapun bahan baku yang disampaikan dalam pelatihan untuk pembuatan dodol buah naga yakni, $10 \mathrm{Kg}$ Buah naga yang masak: hal ini bertujuan agar warna yang dihasilkan maksimal; 5 Kg tape singkong; $3 \mathrm{Kg}$ tepung tapioka; 250 gr Gula pasir (sesuai selera); 2 liter Minyak goreng serta Garam secukupnya.

Materi pelatihan yang kedua yakni mengenai Packaging product agar tidak hanya mengandalkan rasa produk yang enak tetapi juga menampilkan hal yang menarik agar produk tersebut memiliki nilai jual yang tinggi. Pelatihan kedua ini dilaksanakan pada tanggal 28-29 Oktober 2017 di tempat yang sama. Adapun materi yang disampaiakan antara lain mengenai pemahaman apa yang dimaksud dengan ekonomi kreatif, apa itu kreatifitas, bagaimana proses pembuatan dus produk yang menarik, dimana dapat mencetak dus tersebut, berapa biaya yang dibutuhkan, dan lainlain. Selain dengan metode ceramah materi juga disampaikan dengan pemutaran video film bagaimana packaging produk dapat memengaruhi nilai jual dan daya tarik pembeli terhadap produk tersebut. Sehingga masyarakat menjadi lebih cepat pemahamannya dan tertarik mengikuti pelatihan hingga selesai. Kemudian pelatihan yang ketiga dilaksanakan pada tanggal 4-5 November 2017 di tempat yang sama dan dihadiri oleh berbagai lapisan masyarakat karena materi tersebut menyangkut bagaimana setelah produk tersebut jadi dan dikemas dengan baik dapat menjadi produk yang paten dan tidak dapat ditiru oleh produsen lain. 
Adanya hubungan peranan pelatihan terhadap peningkatan pendapatan masyarakat di pedesaan merupakan suatu hasil dari proses pelatihan yang telah dilaksanakan. Melalui penyuluhan masyarakat mendapatkan informasi dan berbagai wawasan, sehingga masyarakat dapat memahami secara mendalam tentang ekonomi kreatif serta manfaatnya bagi peningkatan pendapatannya dan juga yang tidak kalah penting adalah bagaimana masyarakat dapat berinovasi untuk meningkatkan nilai jual terhadap sumber daya alam di desa tersebut terutama buah naga. Bahkan menurut Arif, Ana Wulandari dan Inung (2017) menyebutkan bahwa pemahaman masyarakat sebelum mendapatkan pelatihan dengan sesudah mendapatkan pelatihan mempengaruhi pemahamannya hingga 56\% untuk mengembangkan inovasi mengenai apa saja yang ada di desa tersebut untuk mengembangkan ekonomi masyarakat.

Keberhasilan kegiatan ini tampak dengan diterimanya materi dalam pelatihan berlanjut sampai digunakannya ide baru tentang pengolahan buah naga menjadi dodol buah naga. Namun untuk memperoleh hasil yang lebih maksimal hal yang dapat dilakukan adalah diperlukan kegiatan lanjutan yang bersifat pendampingan masyarakat sehingga mereka terus bisa menekuni usaha yang akan dibuat. Hambatan yang ditemui pada saat pelatihan adalah menyesuaikan jadwal masyarakat dengan jadwal kegiatan karena hampir seluruh mereka bekerja sebagai petani di siang hari. Selain itu jauhnya keberadaan desa ini dari pusat kota juga menjadi kendala untuk berkunjung ke wilayah ini dan melakukan pembinaan serta mengonfirmasi keberlanjutan kegiatan pada masyarakat. Seluruh masyarakat penerima materi pelatihan berharap akan ada keberlanjutan kegiatan ini dengan pelatihan di lain waktu serta masyarakah berharap akan ada pembinaan ke depannya.

\section{HASIL YANG DICAPAI}

Hasil yang telah dicapai sebesar 100\% yaitu telah berjalannya semua kegiatan kami, yaitu :

Tabel 4.l Hasil dan Capaian Kegiatan

\begin{tabular}{|c|l|l|c|l|}
\hline No & \multicolumn{1}{|c|}{$\begin{array}{c}\text { Tahap } \\
\text { Kegiatan }\end{array}$} & \multicolumn{1}{|c|}{ Nama Kegiatan } & $\begin{array}{c}\text { Tanggal } \\
\text { Kegiatan }\end{array}$ & Hasil Kegiatan \\
\hline 1 & $\begin{array}{l}\text { Tahap } \\
\text { Pelaksanaan 1 }\end{array}$ & $\begin{array}{l}\text { Koordinasi dengan } \\
\text { perangkat desa untuk } \\
\text { turut serta dalam } \\
\text { kegiatan pelatihan }\end{array}$ & $\begin{array}{c}\text { Sabtu, } \\
2 \text { Oktober } \\
2017\end{array}$ & $\begin{array}{l}\text { Ditentukannya lokasi } \\
\text { pelatihan dan peserta } \\
\text { yang akan datang. }\end{array}$ \\
\cline { 3 - 5 } & $\begin{array}{l}\text { Pelatihan Pembuatan } \\
\text { Dodol Buah Naga yang } \\
\text { Sehat }\end{array}$ & $\begin{array}{c}\text { Minggu, } \\
\text { 22 Oktober } \\
\text { 20l7 }\end{array}$ & $\begin{array}{l}\text { Audiens mendapat } \\
\text { pengetahuan tentang } \\
\text { pembuatan dodol } \\
\text { buah naga yang baik } \\
\text { serta dihasilkannya } \\
\text { produk dodol buah } \\
\text { naga yang sehat dan }\end{array}$ \\
\hline
\end{tabular}




\begin{tabular}{|c|c|c|c|c|}
\hline & & & & tahan lama. \\
\hline & \multirow{3}{*}{$\begin{array}{l}\text { Tahap } \\
\text { Pelaksanaan } 2\end{array}$} & & & \\
\hline \multirow[t]{2}{*}{2} & & $\begin{array}{l}\text { Koordinasi dengan } \\
\text { perangkat desa untuk } \\
\text { turut serta dalam } \\
\text { kegiatan pelatihan }\end{array}$ & $\begin{array}{c}\text { Sabtu, } \\
28 \text { Oktober } \\
2017\end{array}$ & $\begin{array}{l}\text { Ditentukannya lokasi } \\
\text { pelatihan dan peserta } \\
\text { yang akan datang. }\end{array}$ \\
\hline & & $\begin{array}{l}\text { Pelatihan Packaging } \\
\text { dodol buah naga }\end{array}$ & $\begin{array}{c}\text { Minggu, } \\
29 \text { Oktober } \\
2017\end{array}$ & $\begin{array}{l}\text { Audiens mendapat } \\
\text { pengetahuan tentang } \\
\text { pengemasan dodol } \\
\text { buah naga yang } \\
\text { menarik dan praktis. }\end{array}$ \\
\hline
\end{tabular}

\begin{tabular}{|l|l|l|c|l|}
\hline 3 & $\begin{array}{l}\text { Tahap } \\
\text { Pelaksanaan 3 }\end{array}$ & $\begin{array}{l}\text { Koordinasi dengan } \\
\text { perangkat desa untuk } \\
\text { turut serta dalam } \\
\text { kegiatan pelatihan }\end{array}$ & $\begin{array}{c}\text { Sabtu, } \\
4 \text { November } \\
2017\end{array}$ & $\begin{array}{l}\text { Ditentukannya lokasi } \\
\text { pelatihan dan peserta } \\
\text { yang akan datang. }\end{array}$ \\
\cline { 2 - 4 } & Pelatihan HAKI & $\begin{array}{c}\text { Minggu, } \\
5 \text { November } \\
2017\end{array}$ & $\begin{array}{l}\text { Audiens mendapat } \\
\text { pengetahuan tentang } \\
\text { bagaimana caranya } \\
\text { mematenkan merk } \\
\text { sebuah produk untuk } \\
\text { memberikan } \\
\text { perlindungan hukum } \\
\text { atas produk tersebut. }\end{array}$ \\
\hline
\end{tabular}

Potensi hasil yang dicapai dari program ini yaitu:

1. Meluasnya inovasi pengolahan produk buah naga menjadi dodol dan lain-lain sehingga desa Temurejo dapat menjadi sentral produksi olahan buah naga,

2. Adanya pengolahan yang baik dari produsen dapat meningkatkan nilai tambah dari buah naga tersebut,

3. Program lanjutan terkait penguatan Industri Puspa Naga yakni fokus pada bantuan pengurusan merk produk dodol agar produksi Puspa Naga dapat beredar secara luas di pasaran.

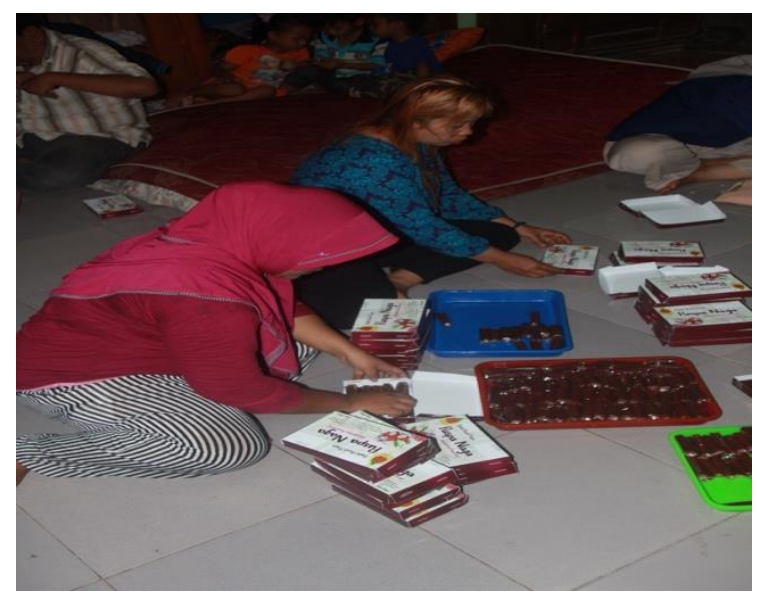



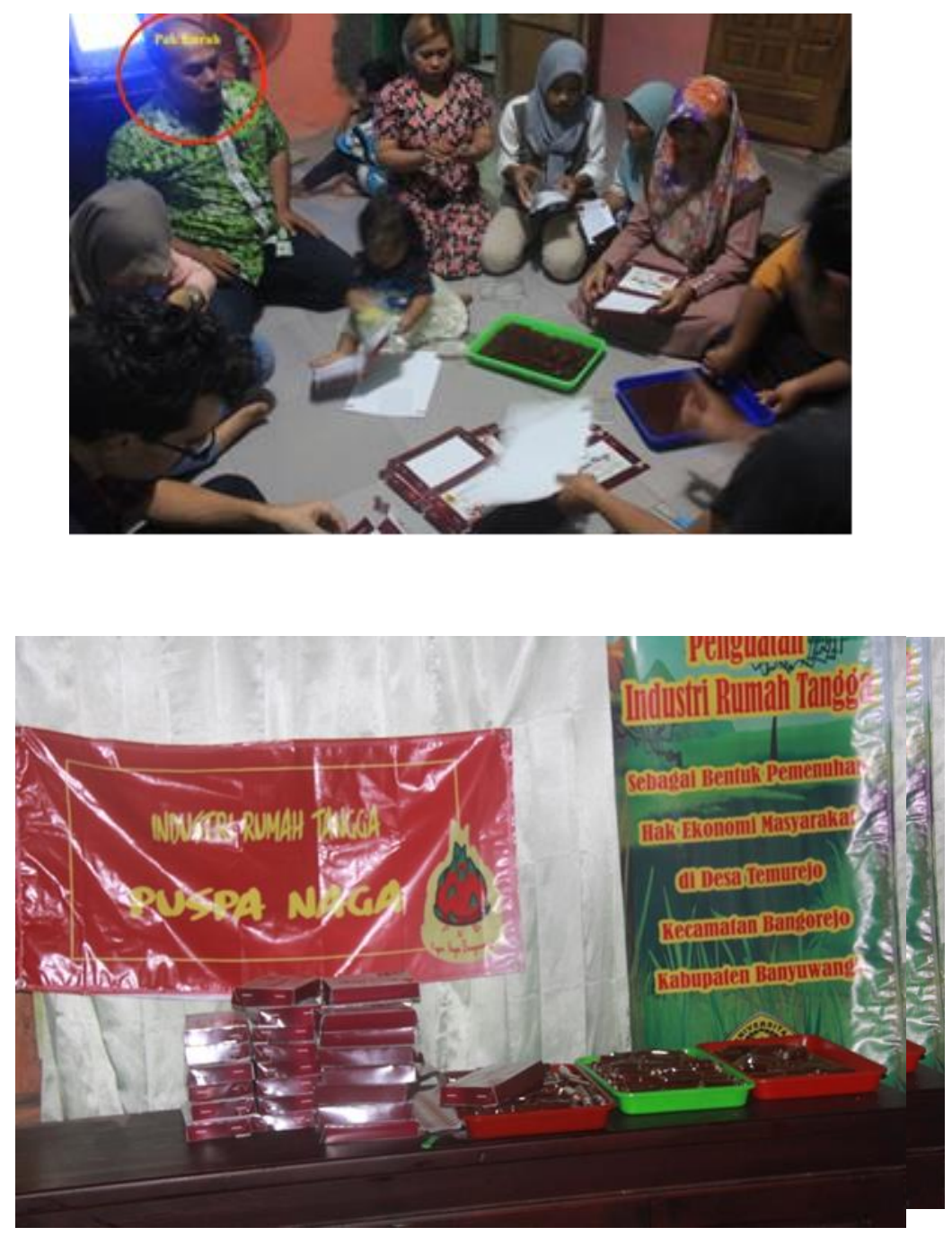

BAB V. KESIMPULAN

Ada beberapa hal yang dapat disimpulkan dari program pengabdian untuk memperkuat industri rumah tangga Puspa Naga tersebut. Yang pertama, intervensi desa/pemerintah terhadap pengembangan dodol buah naga sebagai salah satu industry kreatif masyarakat di desa Temurejo masih belum maksimal. Diperlukan kajian dan keterlibatan dari pihak ketiga secara mendalam untuk menyelesaikan persoalan keterlibatan/intervensi desa untuk memaksimalkan potensi ekonomi desa.

Yang kedua adalah pengetahuan pengrajin buah naga terkait pengemasan dan kontrol kualitas dodol buah naga yang masih buruk. Selama program berlangsung, rasa dan ukuran dodol yang dihasilkan tidak pernah sama. Tentu harus ada standarisasi produk yang jelas dan ini harus dilakukan oleh pemerintah (desa) atau pihak ketiga untuk memberikan penyuluhan kepada pengrajin dodol. 
Yang terakhir adalah mengenai pendaftaran produk agar dodol buah naga Puspa Naga dapat beredar di pasaran. Perijinan tentu tidak dapat dibebankan ke pengrajin mengingat proses pendaftaran memerlukan waktu dan biaya yang cukup lama dan besar. Oleh karena itu, program lanjutan terkait penguatan industri puspa naga diharapkan fokus pada bantuan pengurusan merk produk dodol agar produksi Puspa Naga dapat beredar secara luas di pasaran.

Mengingat banyaknya jumlah petani buah naga serta besarnya hasil panen, maka kegiatan pengabdian sejenis dirasa penting. Kegiatan pengabdian ini juga mendapat respon positif dari masyarakat dalam aspek kebermanfaatan. Oleh karena itu pengusul berharap adanya program lanjutan dari pengabdian ini untuk menetapkan HAKI. 